\title{
Nursing teachers teaching about death: challenge in the academic process*
}

\author{
Ensino da morte por docentes enfermeiros: desafio no processo de formação acadêmica
}

Márcia Gabriela Rodrigues de Lima ${ }^{1}$, Elisabeta Albertina Nietsche ${ }^{1}$

Objective: to understand the strategy used by nursing teachers for teaching about death in theoretical and practical activities of the Nursing Course. Methods: qualitative research with 14 Nursing teachers, through sampling by data saturation in a public institution of higher education. A semi-structured interview was used for data collection and Content Analysis was performed. Results: the teachers believed to be relevant teaching about death, however, many do not do it, highlighting as a limitation the bond with the patient, death in childhood, the feelings, personal values and the absence of specific disciplines. Conclusion: the way death is perceived influences the approach of this theme in teaching Nursing.

Descriptors: Education; Death; Nursing.

Objetivo: compreender a estratégia utilizada por docentes enfermeiros para o ensino acerca da morte em atividades teórico-práticas do Curso de Enfermagem. Métodos: pesquisa qualitativa, com 14 docentes em Enfermagem, por meio da amostragem por saturação de dados, em instituição pública de ensino superior. Utilizou-se a entrevista semiestruturada para coleta de dados e realizada Análise de Conteúdo. Resultados: as docentes acreditavam ser pertinente ensinar sobre a morte, entretanto, muitas não o fazem, destacando como limitação o vínculo com o paciente, a morte na infância, os sentimentos, valores pessoais e ausência de disciplinas específicas. Conclusão: a forma como a morte é percebida influencia na abordagem dessa temática no ensino em Enfermagem.

Descritores: Educação; Morte; Enfermagem.

\footnotetext{
*Article extracted from the dissertation "Representações sociais sobre a morte para docentes enfermeiros e suas influências no ensino", Universidade Federal de Santa Maria, 2013.

${ }^{1}$ Universidade Federal de Santa Maria. Santa Maria, RS, Brazil. 


\section{Introduction}

Numerous scientific publications in various areas have strongly approached the event of death as a painful problem to mankind, that brings up memories of past losses, the pain of grief, the feeling of finishing and the fear of the unknown and uncertain future ${ }^{(1)}$.So, thinking about the finitude is not easy, nor desirable, despite daily media have been reporting, often in a trivialized manner, about the death of several people.

In this context, considering that the educational space has the function to promote socialization, it is necessary to open up space for several themes ${ }^{(2)}$. However, this practice becomes a challenge, especially for teachers of courses in the health field, such as nursing, because many of them have not received training/qualifications required to discuss this event in the classroom or even feel apprehensive, which limits the performance, complicates the process of teaching and disqualifies the training of new professionals ${ }^{(3)}$.

Therefore, the difficulty alleged by teachers in talking about dying and death in classroom is related to the lack of preparation as a professional, which is a proven fact in the gaps left during the academic training and in the apprehension raised ${ }^{(4)}$. Moreover, often, educational institutions point to the impossibility to address the issue due to lack of time and human resources or stating that this is a subjective issue, and therefore should not be discussed in the educational space ${ }^{(5)}$.

However, it is necessary that nursing teachers are prepared to optimize the process of teaching and learning about death. They will be able to support students who have emotional difficulties when faced with death in the fields of practical lessons; and to implement the training of nurses with a humanized vision of care at the stage of human terminal illness.

On the face of it, the guiding problem of this study was: how do nursing teachers approach the process of dying and death in teaching theoretical and practical activities at the Graduate Program in Nursing?
The objective was to understand the strategy used by nursing teachers for teaching about death in theoretical and practical activities of the Nursing Course.

\section{Methods}

This is a qualitative research, carried out with nursing teachers of the Nursing Department of a public higher education institution in the state of Rio Grande do Sul / Brazil. The inclusion criteria for the subjects was being effective teachers. Exclusion criteria were being part of other university units of the institution, being advisor professor of the study, being on vacation, leave, under medical certificate or removal of any other nature.

Thus, 14 teachers participated in the data collection; there was theoretical saturation of data, as the content of the participants' speeches started to repeat. As a data collection instrument, authors used the semi-structured interviews with open questions: questions about the teaching of death (relevance of teaching on the subject, addressing death in nursing care with the students in classroom, difficulty to talk about death).

The invitation to participate in the research was conducted through personal contact with each professor, according to their working days in the institution. In this first moment, it was explained about the project and how the activities would occur. For those who agreed to participate, the interview was already scheduled.

The interview took place individually in previously scheduled locations and times, respecting the production and feelings of each participant. The speeches were recorded and transcribed later. The approximate period of the data collection corresponded to the months from May to July 2012.

The process of analysis, discussion and interpretation of the data was driven by content analysis technique ${ }^{(6)}$. In the pre-analysis it was carried out initial reading of the first interviews to check whether 
they were responding to the research objectives. Therefore, the rules of completeness, representativeness, consistency, relevance and exclusivity were respected $^{(6)}$. The material exploration was based on the encoding, with the transformation of raw data to reach the meaning core of the text. After, there was the clipping of text in record units to list the categories, grouping when there was similarity. In the treatment of the results and interpretation, the themes were placed in evidence and researchers proceeded to the re-reading of the categorized material to enable a critical reflection of results. The privacy and confidentiality of the subjects were maintained by use of the letter " $\mathrm{T}$ " (teacher), followed by numbers D1, D2, D3.

The study complied with the formal requirements contained in the national and international regulatory standards of research involving human beings.

\section{Results}

From the data collected in this study, the following themes emerged: relevance of teaching about death in academic training, teaching strategies to address death and limitations in teaching about death.

\section{Relevance of teaching about death in academic training}

All the fourteen participants considered teaching about the process of dying and death relevant in the undergraduate course in Nursing, as exemplified in the speeches: It is essential because death is part of our daily lives. We are health professionals, we deal with health, with disease and death. Terminality is another issue that has to be addressed, student must be prepared for it (T3); I find it very important that the professional, the teacher, transmit a few concepts for this group (students) that will be professionals. We have to inform students that nursing plays an important role at this time, they can just stay with the family, listening to what they have to say (T6).
They said it is pertinent to address death still in the training period to assist in the construction of the professional identity of the student, so that they recognize their social role as a nurse and member of the healthcare team, taking responsibility for humanized and comprehensive care to the individual and their family throughout the entire life cycle.

Another discussed issue was about opening space in the classroom to promote discussion of death: We still work hard in training related to the individual actions of the patient, to the performance of the nurse during the course throughout the disciplines, but not like this, involving the family (T1); I think it is crucial to address the death theme, because our students must be prepared or at least monitor the situation, to experience this and be prepared for these situations they will face (T2).

Participants stated the relevance of generating spaces that facilitate the teacher/students interaction for discussion about the process of dying and death in academic practice, as well as the sharing of raised feelings, as moments like this are rarely found in the teaching method used. Thus, this would enable the student to work in an authentic manner, provide individualized and non-mechanistic care.

In addition, three teachers pointed out that addressing death in academic teaching becomes relevant by the inexperience and immaturity of many students. The following statements exemplify this: $I$ think so, it is relevant to address this theme because the student who enters the course usually still has their grandparents and parents. So they will meet death with unknown people, but people to whom they have to provide care (T10); I think it is relevant because we have young students, with less structure to deal with difficulties, very immature in many aspects and with emotional lability (T12).

From these speeches, it was found that addressing death in Nursing undergraduate course is relevant because some students have been entering university very young, and many of them still do not have enough experience and maturity to deal with situations of human suffering and terminally, often experienced in the daily routine of nurses. 
On the other side, some reported being relevant to talk about death due to the complexity of each area where the teaching practice is developed: I find it very important because students, when they see it is a child in a severe condition, they get very scared and cannot even imagine death. There must be a different approach (T4); I cannot see the training process without talking about it. I have always approached this, even because of the peculiarity of the environment I work with the students, which is in the Intensive Care Unit. There are students who get really emotional, they cannot deal with the feelings caused by that reaction and we need to resume at other times during the practice field (T5).

From this perspective, these words emphasized that promoting education about the process of dying and death in classes may raise less suffering to students who are experiencing or will experience practical classes where critical care is provided, such as pediatric unit or intensive care, since in the first, death is present in childhood and in the last, its presence is constant.

\section{Teaching strategies to address death}

Despite the teaching about dying and death enables students to know and develop a set of relevant values and attitudes to their relationship with the patient and the family, four professors pointed out that they did not address the process of dying and death: I do not address the death theme, although I develop my activities in critical situations, i.e., in risk of imminent death. But this is not addressed, we do not have a specific discipline for this (T1); I work in primary care, where we talk less about death. Here I feel we end up working a lot with guidance, with education and health for growth, development, we see the side of life more often (T8).

These statements unveiled that the issue was addressed only when death occurred in some curriculum content of the Undergraduate Nursing Course, such as primary care and women's health. This is justified by the participants for having little or no death situation during practical classes, also for students are often newly entering the course or because the death issue was not part of the content that focused on life.

Four teachers claimed they addressed the issue only when it emerged in practical classes: We address it when it appears on the practice field. Sometimes I talk to students: Look at this child, he has this chronic disease, perhaps he will not reach adolescence. Students get a little shocked (T4); The way to address it is more with conversations, because in fact we develop it in practice when this happens, rescuing these contents and issues involved in a collective discussion there in the same field (T14).

Regarding these expressions, it was observed that the teaching of death occurred only when there was a terminally ill patient.

On the other hand, six teachers reported they addressed death in their teaching activity: I talk about death with students on the issue of abortion in hospital (T6); I address it on the Supplementary Discipline of the Graduation, where one of the issues we address is death.I usually bring a movie to talk about the feelings (T9); I talk about it in the classes, that managing the patient's death is also important, as knowing the whole issue that the family does not want the patient to die at home, even though there is nothing more to do for that person (T10).

As the speeches show, teaching about death occurred in lectures of a Supplementary Discipline through films, and at times in the Discipline of Management of Health Services. In practical classes this approach happened in obstetrics area, through group discussions, sometimes before and/or after observing death situation.

\section{Limitations in teaching about death}

Despite the daily confrontation with death, many health professionals found it difficult to face it, as emphasized: The death of a patient also has an impact on me. Sometimes I do not know how to deal with the reaction of the family because we have to respect their anguish, their suffering, we have to be available while waiting to see what they expect from us (T2); We think we are, but we are never prepared for losses, and depending on the bond we form with people and the family, the loss is more or less meaninful (T14). 
The relationship built with the patient and their family throughout the completion of the care plan was seen by teachers as a limitation for teaching about death.

The death of children and young people was also identified as a limiting factor in teaching in the practical field: One of the hardest things is to deal with the death of a child, a teenager, a young adult, it seems that this kind of event is not possible, it is not accepted so well as in an elderly person (T3); The death of a child is a poorly approached in our discipline, we do not address this officially in the curriculum. In fact, we work with the students thinking to protect them (T4).

Teaching about death in childhood and youth does not occur effectively in universities, because at this stage of life, it is strange to both teachers and students and to other professionals, as these phases represents life.

Death as an event that raises feelings and values was also highlighted as a limiting factor to teaching: Teaching about death is more difficult because it involves our values, feelings, first as a teacher, a person, a human being, not only as a nurse, a professor (T1); There are things we teach in the classroom and things we do not manage to teach. Sometimes, even though we say cannot manage it because it's something that we have experienced (T7).

The absence of specific disciplines for the teaching of death was indicated as a limitation: We spend so much time not talking about the death theme that I have this concern too, will we never put it in any discipline? (T1); This theme should be better taught in a formal space so that we can discuss, and this discussion, as teaching space, must not be a technical discussion, it must go through the issue of formation of the "self" (T9).

Thus, teachers have ensured that addressing death in the classroom, either in theory or in practice, would be less difficult if there was a specific formal space for discussion, addressing not only procedural and technological aspects of care, but also the emotional and personal aspects of each student.

\section{Discussion}

The limitations found in this study were the number of subjects participating in the data collection, for it enable us to know the reality of the teaching about death in the nursing course only in the scenario under study and not more broadly, in other institutions education in the country. Another issue was the consequence of the failure of that teaching from the students' perspective, since the focus of this study was not interviewing students.

Through the results obtained, it was possible to understand how the teachers of the Nursing Undergraduate Course experience the death theme in their daily teaching with the students. This practice proved to be still deficient, despite being a constant theme in nursing work environment.

Thus, it is understood that the nursing professor expressed in their practice a kind of escape from the death theme, since it arouses feelings of helplessness, sadness, uncertainty, and especially anxiety by addressing something that is also inherent in them: the finiteness of life. The impact of death is not necessarily transformed into an experience as it is an event that produces a unique meeting in each individual ${ }^{(7)}$.

Currently, death has been an interdict theme and education that is offered to health professionals is no different from the rest of society ${ }^{(8-9)}$. The structural form of undergraduate nursing curricula in Brazil was and still is disciplinary, technicist and focused on disease $^{(4)}$. A similar situation was found in a survey of 91 Canadian nursing schools, by the Canadian Association of Schools of Nursing, which revealed inadequate teaching about death in these educational spaces $^{(10)}$.

Some students enroll in health courses very young, which reflects in lack of preparation and 
clearance to take care of patients in the process of dying and death in the daily curriculum practices ${ }^{(10)}$. Such immaturity is still observed in the classroom, since they often have not assimilated that their future work object is the care of other people's lives; nor on the implications that the responsible and effective professional practice will exercise in the patient's treatment or that the care will be directed both to sustain life and to support those who are in the process of dying and death.

Students' learning is often lonely and comes from their own need ${ }^{(11)}$. Later, as a professional, when faced with death situations to which do not get used, because dealing with it is painful, they experience much suffering and mechanization of their actions ${ }^{(12)}$.

This demonstrates the need of support in the first professional experiences of death, so that, through this support, nurses are able to organize feelings and build a professional work, without feeling lost with respect to the sensations ${ }^{(13)}$. The face of death is a difficult process and the attention given by humans to this theme is complex and interwoven by biopsychosocial connotations that should be taken into account both in the training of nursing students and in the organization of care practices, as it is often relegated up to a secondary plan, becoming therefore a social act instead of a technical act ${ }^{(14)}$.

In this sense, the teacher plays a key role in approaching the student with the scenario of care before dying and death, as this provides information, enriches and consolidates academic knowledge ${ }^{(12)}$. Study conducted with professors of the health area reveals that most of them do not address the issue of death in the educational activity, and when they do it, it is superficially and quickly, usually during the last six months of graduation, instead of permeating all the training process $^{(12)}$.

So, in teaching nursing, it is seen that death takes place in the curriculum as mere accessory and does not receive significant workload nor theoretical approach $^{(15)}$. Generally, so that there is teaching, one must witness a fact, otherwise the theme is not addressed $^{(12)}$.

This deficiency can be ruled in singularities, particularities, values and emotions that each teacher feels or attaches to address theoretical and practical content $^{(13)}$, situations such as the breaking that death causes in the bond between patient and professional; confrontation with death in critical and intensive care units or terminal illness in childhood/youth.

In nursing, the confrontation with death in childhood may represent something "worse" because it is interpreted as an interruption of the biological cycle, setting up as a trigger source of emotional stress both for the teacher and for the student ${ }^{(11)}$. Another study of nursing teachers showed that the feelings aroused by the thematic approach of death were: sadness (41.5\%), fear and anxiety (15.1\%), confrontation (5.6\%), depression (3.8\%) and anger $(1.9 \%)^{(15)}$.

The human finitude in its essence causes strangeness to those who are alive but need to witness it. "The care of a patient, before the possibility of imminent death, implies that who watches may have a variety of feelings as compassion, anguish and fear, causing pain and suffering to themselves"(16:76). This contact with the patient may be a shock for those who are faced with human frailty and complexity of problems involving the person in this situation ${ }^{(17)}$.

So, in an attempt to change this reality, teaching about dying and death should be privileged in all curricula of health courses, since it enables the students to know and develop a set of values and relevant positions in the relationship with the patient and their family. These elements are essential to the formation of conscious individuals and able to make responsible decisions and implement a humanized care in face of human terminality

\section{Conclusion}

Given the above, this study considers the strategy used by nursing teachers for teaching about death in theoretical and practical activities of 
nursing course. The approach of this issue happens infrequently and not transversely between the course content, but when it happens, it is in the face of terminal patients in practical classes fields or in groups of students in complementary disciplines of graduation. Thus, there is not a specific strategy for this teaching; it is addressed where there is a situation that makes discussion inevitable.

Although this study shows a circumscribed reality, teachers reported difficulties in teaching about human finitude. So, this practice is not an easy activity, but rather complex, even though it is essential for the care to the person and not only to the biological body. To enable an education directed for dying and death, still in the training process of nurses, it is not enough applying insufficient measures, such as reformulating curricula creating new disciplines or defragmentation of content. However, it is essential that teachers and students reflect together on the meaning, singularities and pluralities of death.

\section{Collaborations}

Lima MGR contributed to the project design, analysis of the results, article writing and final approval of the version to be published. Nietsche EA contributed to the project design, data collection, article writing and critical review of the relevant intellectual content and final approval of the version to be published.

\section{References}

1. Santos MA, Hormanez M. Atitude frente à morte em profissionais e estudantes de enfermagem: revisão da produção científica da última década. Ciênc Saúde Coletiva. 2013; 18(9):2757-68.

2. Kovács MJ. Educação para a morte: temas e reflexões. São Paulo: Casa do Psicólogo; 2003.
3. Santos JL, Corral-Mulato S, Bueno SMV. Morte e luto: a importância da educação para o profissional de saúde. Arq Cienc Saúde UNIPAR. 2014; 18(3):199-203.

4. Ribeiro DB, Fortes RC. A morte e o morrer na perspectiva de estudantes de enfermagem. Rev Divulg Cient Sena Aires. 2012; 1(1):32-9.

5. Benedetti GMS, Oliveira K, Oliveira WT, Sales CA, Ferreira PC. Significado do processo morte/ morrer para os acadêmicos ingressantes no curso de enfermagem. Rev Gaúcha Enferm. 2013; 34(1):173-9.

6. Bardin L. Análise de conteúdo. Portugal: Edições 70; 2011.

7. Chagas MS, Merhy EE, Abrahão AL, Cerqueira MP, Silva E. The caring in face of the finiteness in the hospital institutions: a descriptive study. Online Braz j Nurs [Internet]. 2013 [cited 2016 Mar 20]; 12(supl) Available from: http://www.objnursing. uff.br/index.php/nursing/article/view/4546/ html_1

8. Lima MGR, Nietsche EA, Santos SC, Teixeira JA, Bottega JC, Nicola GDN et al. Revisão integrativa: um retrato da morte suas implicações no ensino acadêmico. Rev Gaúcha Enferm. 2012; 3(33):1907.

9. Vogel L. Nursing schools to teach new ways to cope with death. CMAJ [Internet]. 2011 [cited $2016 \mathrm{Mar}$ 20]; 183(4):418. Available from: http://www. ncbi.nlm.nih.gov/pmc/articles/PMC3050945/ pdf/1830418.pdf

10. Medeiros YKF, Bofanda D. Refletindo sobre finitude: um enfoque na assistência de enfermagem frente à terminalidade. Rev Rene. 2012; 13(4):845-52.

11. Ferreira RA, Lira NPM, Siqueira ALN, Queiroz E. Percepções de psicólogos da saúde em relação aos conhecimentos, às habilidades e às atitudes diante da morte. Psicol Teor Prát. 2013; 15(1):6575 .

12. Borges MS, Mendes N. Representações de profissionais de saúde sobre a morte e o processo de morrer. Rev Bras Enferm. 2012; 65(2):324-31. 
13. Menossi MJ, Zorzo JCC, Lima RAG. The dialogic lifedeath in care delivery to adolescents with cancer. Rev Latino-Am Enfermagem. 2012; 20(1):126-34.

14. Perdigon AGC, Strasser G. El proceso de muerte y la enfermería: un enfoque relacional. Reflexiones teóricas en torno a la atención frente a la muerte. Physis. 2015; 25(2):485-500.

15. Bandeira D, Bastos C, Silvana H, Leila M, Rossato MB. A morte e o morrer no processo de formação de enfermeiros sob a ótica de docentes de enfermagem. Texto Contexto Enferm. 2014; 23(2):400-7.
16. Alves MVMFF, Scudeler DN, Luppi CHB, Nitsche MJT, Toso LAR. Morte e morrer em Unidade de terapia Intensiva Pediátrica: percepção dos profissionais de saúde. Cogitare Enferm. 2012; 17(13):543-8.

17. Salimena AMO, Ferreira GC, Melo MCS. Sentimentos da equipe de enfermagem cirúrgica diante da morte. Arq Ciênc Saúde. 2015; 22(1):75-78. 